\title{
Relationship between Company Financial Performance, Characteristic and Environmental Disclosure of ASX Listed Companies
}

\author{
Indah Fajarini Sri Wahyuningrum ${ }^{1 *}$ and Mochamad Arief Budihardjo $^{2}$ \\ ${ }^{1}$ Department of Accounting, Faculty of Economic, Semarang State University, Semarang - Indonesia \\ ${ }^{2}$ Department of Environmental Engineering, Faculty of Engineering, Diponegoro University, Semarang - Indonesia
}

\begin{abstract}
The study expects to find positive relations between company financial performance, company characteristics, auditing firm, and the extent of company environmental disclosure. The sample data used in this study is 200 largest Australian listed companies (ASX) in 2014. In order to explain the corporate social responsibility practices in Australian companies, this study used stakeholder and legitimacy theories. The measurement of company environmental disclosure in this study involves nine indicators of environmental disclosure index based on Environmental Social and Governance (ESG). More specifically, the statistical analysis indicates that earnings per share, return on equity, type of company, size of company, age of company, and auditing firm positively influence the company environmental disclosure. On the other hand, the results showed that return on assets has no relationship with company environmental disclosure. Overall, this study has added some information about corporate social disclosure studies focused on environmental disclosure of largest Australian companies.
\end{abstract}

Keywords: environmental disclosure; company financial performance ; company characteristics

\section{Introduction}

Companies have responded favourably to the need for a more socially responsible approach to business, and increased public scrutiny of their activities. According to [1], a sustainability report provides information based on economic, environmental, social, and governance performance. A sustainability report can be a major tool for companies to communicate the positive and negative effects of sustainability, and can assist them with achieving their objectives, measuring their performance and managing change.

According to several Australian studies previously, sustainability reporting has focused on the environmental practices of companies [2]. Recently, there has been limited analysis of disclosures particularly on general social issues. According to KPMG (2011) [3], Australia fell behind many other countries in its sustainability reporting, and was ranked $23^{\text {rd }}$ of 34 countries studied. A total of 57 per cent of companies reported on corporate responsibility compared to $45 \%$ of companies in KPMG's 2008 study. Even though there was a slight increase in sustainability reporting, Australia position was behind some countries such as the United States, South Africa, Russia, Nigeria, China, and Mexico. Based on this, it is evident that Australian companies need to place more emphasis on accomplishing an adequate standard of sustainability reporting [4].
The Environmental, Social, and Governance (ESG) aspects have been brought to companies' attention since the 1970s [5]. The ESG includes the three main areas of key performance indicators (KPIs) which are environment (e.g. carbon emissions, climate change, energy and water use), social responsibility (e.g. health and safety, human rights, fair trade principles, product safety and gender quality) and governance (e.g. corruption and bribery, board independence, reporting and disclosure and shareholder protection).

In the ESG framework, the environmental aspect has become a foremost issue in recent years. This study will focus only on the extent of the environmental disclosure of 200 largest Australian listed companies using nine items in ESG framework. The environmental aspect includes relevant information such as pollution, climate change and technological aspects that are important for disclosure. The following items specify the environmental aspect in the ESG framework for this study:

\section{a. Natural Resources Use}

Companies are measured on which natural resources they use and how they manage them, including:

1. Materials

2. Energy and renewable energy

3. Water

Corresponding author: i.fajarini@gmail.com 
4. Land

5. Biodiversity

b. Environmental pollution

1. Companies are rated according to how they manage their emissions, effluents and waste.

2. Restoration or anticipation of damage to the environment.

3. Companies achieve environmental quality program certifications or receive awards related to the recognition of environmental policies, or penalties against the environmental regulations.

4. Companies are rated on their environmental management systems and compliance.

Previous studies indicated various results on the correlation between financial performance and environmental disclosure of companies. Some studies showed a correlation, either positive or negative, and others found no correlation. [6] found that corporate social disclosure had no relation to financial performance, based on research that used $125 \mathrm{New}$ Zealand listed companies. ROA and ROE were employed to measure the companies' financial performances.

H1: ROA has positive correlation to environmental disclosure of companies.

$\mathrm{H} 2$ : ROA has positive correlation to environmental disclosure of companies.

H3: EPS has positive correlation to the extent of environmental disclosure of companies.

The relationship between characteristics of company and company social disclosure focus on environmental disclosure has been scrutinized by numerous scholars [7]. Most of the studies' results provide evidence that company characteristics (e.g. type of industry, company size, company age, etc.) have relationships. Some studies depend on different theories to justify, and give more detail about, these relationships.

In this study, sensitive and non-sensitive industries were categorised based on previous studies.

H4: Sensitive industries show a higher extent of environmental disclosure than non-sensitive industries.

Total assets are applied in this study as a proxy of company size.

H5: Size of company is positively related to the environmental disclosure.

There were some findings that showed a different correlation between age and environmental disclosure of companies. Some previous studies stated that company age did not significantly affect environmental disclosure [8].
H6: Company age has correlation to environmental disclosure.

Since big auditing firms are more concerned with their own image, and have better reputations than others, they tend to be involved with companies that offer sufficient information about their company activities. Because big auditing firms usually provide more evidences in their reports rather than small auditing firms.

H7: Companies audited by Big Four auditing firms provide a higher extent of environmental disclosure than companies audited by non-Big Four auditing firms.

\section{Methods}

The data collected for this paper is sourced from 200 largest companies (by market capital) listed on the ASX and used company annual and sustainability reports for content analysis during the year of 2014. All companies in this study are classified in 10 different sectors referring to the classification introduced by the Global Industry Classification Standard (GICS). Sustainability reports and other governance information were obtained from various sources, including ASX websites (www.asx.com.au) and individual company websites.

The empirical findings from the content analysis were utilised to describe quantity of environmental disclosure in the sustainability and annual reports of the companies. Data sources for company financial performance; return on assets (ROA), earnings per share (EPS) return on equity (ROE); company characteristics; size, age, and leverage are obtained from each company's annual reports. Type of industry divided into two industry groups based on previous study. These are then dichotomously categorised as sensitive or non-sensitive industries. Auditing firm also dichotomously categorised as company audited by a 'Big Four' auditing firm, or not.

\section{Measurement Variables}

The dependent variable in this study is the extent of environmental disclosure. This variable determined using a unit analysis that consists of individual sentences or an accumulation of sentences into a paragraph, half a page, or one or more pages. The weights given for 'how much disclosure' in this paper based on [9]. A paragraph is defined as a minimum of three sentences or otherwise according to the presentation of the report. Half a page is defined as an accumulation of sentences or paragraphs up to one half page of A4, while the quantity of one A4 page and more than one A4 page also used a similar approach. Any pictures or graphics are omitted when determining the quantity of one A4 page.

The multiple regression model (Ordinary Least Squares or OLS) is used as the main statistical method in this study. In order to minimise cross-sectional variations, one control variable, leverage is involved in the 
regression model. The regression model for this study is as follows:
$\mathrm{ED}=\beta 0+\beta 1 \mathrm{ROAi}+\beta 2 \mathrm{ROEi}+\beta 3 \mathrm{EPSi}+\beta 4 \mathrm{Typei}+$

$\beta 5 \mathrm{SIZEi}+\beta 6 \mathrm{AGEi}+\beta$ AUDITi $+\beta 8 \mathrm{LEVi}+\varepsilon$

Where:

\begin{tabular}{|c|c|c|}
\hline ED & $=$ & Content analysis \\
\hline EPS & $=$ & Ratio of net income deducted dividends on preferred stock divided by average outstanding shares of company \\
\hline SIZEi & $=$ & Total assets of company \\
\hline AGEi & $=$ & Ratio of company age calculated by the number of months company has been established \\
\hline LEVi & $=$ & Ratio of a company's total debt divided by its total assets \\
\hline$\beta_{0}$ & $=$ & Regression constant \\
\hline$\beta_{1,2, n}$ & $=$ & Coefficients of independent and control variables \\
\hline$\varepsilon$ & $=$ & Error of prediction \\
\hline$i$ & $=$ & Company specific \\
\hline
\end{tabular}

\section{Results and Discussions}

Descriptive Analysis

Out of the 200 companies as sample in this study, all companies $(100 \%)$ released their annual reports, 65 companies $(32.5 \%)$ published sustainability reports and 157 companies $(78.5 \%)$ issued information about company activities on their websites. The information about environmental activities can be found not only in their sustainability reports, annual reports but also in their website. This finding shows that the majority of companies prefer displaying their environmental information on their website, rather than providing a stand-alone sustainability report.

Table 1: Number of companies disclosing items of environmental indicator

\begin{tabular}{|l|l|c|c|}
\hline Code & Item indicator & $\begin{array}{c}\text { Number of } \\
\text { Companies } \\
\text { Disclosing }\end{array}$ & $\%$ \\
\hline ENV_1 & Materials & 110 & 55 \\
\hline ENV_2 & Energy and renewable energy & 144 & 72 \\
\hline ENV_3 & Water & 130 & 65 \\
\hline ENV_4 & Land & 100 & 50 \\
\hline ENV_5 & Biodiversity & 73 & 36.5 \\
\hline
\end{tabular}

\begin{tabular}{|l|l|c|c|}
\hline Code & Item indicator & $\begin{array}{l}\text { Number of } \\
\text { Companies } \\
\text { Disclosing }\end{array}$ & \% \\
\hline ENV_6 & $\begin{array}{l}\text { Companies are rated on the extent to which they demonstrate } \\
\text { management of emissions, effluents and waste. }\end{array}$ & 159 & 79.5 \\
\hline ENV_7 & Prevention or repair of damage to the environment & 161 & 80.5 \\
\hline ENV_8 & $\begin{array}{l}\text { Companies achieve environmental quality program certifications } \\
\text { or receive awards related to recognition. Companies achieve } \\
\text { environmental quality program certifications or receive awards } \\
\text { related to the company's environmental policies, or penalties } \\
\text { against the environmental regulation. }\end{array}$ & 113 & 56.5 \\
\hline ENV_9 & Environmental management systems and compliance & 138 & 69 \\
\hline
\end{tabular}

The evidence about the total number of companies that disclose specific items from the environmental disclosure index are presented in table 1. Among these, companies commonly disclose information about prevention or repair of damage $(80.5 \%)$, while biodiversity $(23 \%)$ is disclosed far less than any other indicator.

The findings of descriptive statistics which is showed in Table 2 displays for continuous variables in this paper. 
Table 2: Descriptive statistics

\begin{tabular}{|l|c|c|c|c|}
\hline Variable & Mean & $\begin{array}{l}\text { Standard } \\
\text { Deviation }\end{array}$ & Minimum & Maximum \\
\hline $\begin{array}{l}\text { Dependent } \\
\text { Environmental }\end{array}$ & 1.59 & 1.00 & 0.00 & 3.67 \\
Disclosure & & & & 184.76 \\
\hline Independent & 9.15 & 16.78 & -14.75 & 215.20 \\
ROA & 15.10 & 23.26 & -70.1 & 533.80 \\
ROE & 64.42 & 87.55 & -189.80 & $8.83 \mathrm{E}+0$ \\
EPS & 2529 & 1147 & 148710 & 9.487 \\
Company Size & 222.90 & 198.76 & 2.277 & 5.79 \\
\hline Company Age & 0.52 & 0.51 & -0.5 & \\
\hline
\end{tabular}

Multivariate Analysis

Table 3 presents the multiple regression results of relationships between company financial performances, company characteristics, auditing firmn and the environmental disclosure for the 200 largest Australian companies.

Table 3 : Multiple regression results `

\begin{tabular}{|c|c|c|c|c|}
\hline $\begin{array}{l}\text { Independent } \\
\text { Variables }\end{array}$ & & Coefficient & t-value & p-value \\
\hline Constant & & & 2.415 & .017 \\
\hline ROA & $\mathrm{H} 1$ & .114 & 1.356 & .177 \\
\hline ROE & $\mathrm{H} 2$ & .211 & 2.458 & $.015^{*}$ \\
\hline EPS & $\mathrm{H} 3$ & .205 & 2.977 & $.003 * *$ \\
\hline Company Type & $\mathrm{H} 4$ & .219 & 4.339 & $.000 * *$ \\
\hline Company Size & $\mathrm{H} 5$ & .302 & 5.305 & $.000 * *$ \\
\hline Company Age & H6 & .377 & 7.609 & $.000 * *$ \\
\hline Auditing Firm & $\mathrm{H} 6$ & .173 & 3.465 & $.001 * *$ \\
\hline \multicolumn{5}{|c|}{ Control Variables } \\
\hline Leverage & & .056 & .998 & .320 \\
\hline Adjusted $\mathrm{R}^{2}$ & .563 & & & \\
\hline F-statistic & 32.254 & & & \\
\hline p-value & 0.000 & & & \\
\hline $\mathrm{N}$ & 200 & & & \\
\hline
\end{tabular}

On the other hand, [12] conclude that company

As one indicator of company financial performance, ROA is not significantly related to environmental disclosure $(p$-value $=.177)$. Meanwhile, other indicators of company financial performance; ROE and EPS are related significant. However, type of company, size of company, age of company and auditing firm are significantly related to company environmental disclosure.

Regarding to the multiple regression results, these outcomes are also comparable with prior research. [7] found environmental disclosure to be significantly positively related to company financial performance. [10] findings also suggested that environmental performance disclosure positively correlated to company financial disclosure focus on the manufacturing industry.

Similarly to previous researchers, these results are consistent with former scholars. [11] believed that environmental performance has positive correlation to financial performance of company. The findings indicate that the relationship is significantly influenced by some factors which are, by the measurement of environmental and financial, the activity sector, the difference of each area and the term of the studies. environmental disclosure is not significantly associated to profitability (as a proxy of company financial performance). However, there was a study found that company performance has negatively related to environmental disclosure in 100 Standard and Poor's (S\&P) companies' annual reports in years 2004-2008.

[13] also found that ROA has no relationship with environmental disclosure at a 10\% level of significance. They also discovered that EPS is not correlated with environmental disclosure. However, in their studies, [13] discovered that total assets (company size) is significantly related to environmental disclosure. This may indicate that size has become an key variable that impacts the environmental disclosure.

In general, companies from sensitive industries are more enthusiastic about providing specific environmental information in their reports [14]. In addition, companies may add additional information and verification from auditors about their environmental activities, in order to improve their credibility and image.

Using content analysis, [15] investigated the connection of quantity of environmental disclosure reports (using total number of words) and the quality of environmental disclosure reports. One of the findings indicates that company size influences environmental disclosure. Other results show that market capitalisation 
is positively significant linked to quality and quantity of disclosure. Larger companies provide a precise information of environmental disclosure in their annual and sustainability reports compared to smaller companies $[3 ; 4]$ '.

Company age also has a significant relationship with environmental disclosure at a $10 \%$ level of significance. This means that the more mature a company is, the more likely it is to have a highly valued reputation for environmental disclosure. The public can easily recognise that a company with greater age may provide more information, compared to a new company.

\section{Conclusions}

This empirical study observed the association between company financial performance, characteristics of company and environmental disclosure of the 200 largest Australian listed companies. Overall, most hypotheses in this study have been accepted, with only one being rejected. The findings indicate that the study supports the main results of previous studies. However, there are some limitations in this study which relate to the utilization of a cross-sectional dataset of annual and sustainability reports. This study was only conducted on Australian listed companies. Future studies need to consider using a global database or could be expanded to other regions or countries. Using different countries and regions as a sample dataset to explore the extent of environmental disclosure may change the findings.

\section{References}

1. Elkington, J. Publihing Limited, Oxford. (1997)

2. Frost, G., Jones, S., Loftus, J., \& Laan, S. Australian Accounting Review, 15(35). (2005)

3. KPMG. Retrieved from http://www.kpmg.com/Global/en/IssuesAndInsi ghts/ArticlesPublications/corporateresponsibility/Documents/2011-survey.pdf (2011).
4. Dellios, E. Keeping Good Companies, 64(9), 521. (2012).

5. Humphrey, E. J., Lee, D., \& Shen, Y. Australian Journal of Management, 37(2) (2012).

6. Lima Crisóstomo, V., de Souza Freire, F., \& Cortes de Vasconcellos, F. Social Responsibility Journal, 7(2) (2011).

7. Murray, A., Sinclair, D., Power, D., \& Gray, R. Accounting, Auditing \& Accountability Journal, 19(2), 228-255. (2006).

8. Parsa, S., \& Kouhy, R. Journal of Business Ethics, 79(3), 345-360. (2008).

9. Raar, J. An International Journal, 7(3), 169-183. (2002).

10. Jacobs, B. W., Singhal, V. R., \& Subramanian, R. Journal of Operations Management, 28(5), 430-441. (2010).

11. Albertini, E. (2013). Organization \& Environment, 26(4), 431-457.

12. Qiu, Y., Shaukat, A., \& Tharyan, R. (2016). The British Accounting Review, 48(1), 102116.

13. Malarvizhi, P., \& Matta, R. (2016). The British Accounting Review, 36(1)

14. Cho, C. H., \& Patten, D. M. (2007). Accounting, Organizations and Society, 32(7), 639-647.

15. Lee, K. H. (2016). Business Strategy and the Environment. 